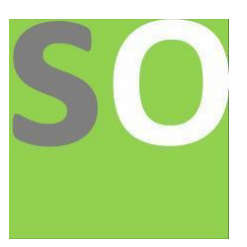

Article title: The Relationship Between Gender, School Location And Students Mathematics Achievement In Secondary Schools In Makurdi

Authors: Ngutor Tembe[1], Shalom Tembe [2]

Affiliations: Department of Mathematics Education, Federal University of Agriculture Makurdi, Nigeria[1], Department of Chemistry Education, Federal University of Agriculture Makurdi, Nigeria[2]

Orcid ids: 0000-0002-7962-3248[1], 0000-0003-3277-4732[2]

Contact e-mail: ngutortembe@gmail.com

License information: This work has been published open access under Creative Commons Attribution License http://creativecommons.org/licenses/by/4.0/, which permits unrestricted use, distribution, and reproduction in any medium, provided the original work is properly cited. Conditions, terms of use and publishing policy can be found at https://www.scienceopen.com/.

Preprint statement: This article is a preprint and has not been peer-reviewed, under consideration and submitted to ScienceOpen Preprints for open peer review.

DOI: 10.14293/S2199-1006.1.SOR-.PPPWQAU.v1

Preprint first posted online: 06 December 2020

Keywords: Gender, School Location, Mathematics Achievement 


\title{
The Relationship between Gender, School Location and students mathematics achievement in secondary schools in Makurdi.
}

\begin{abstract}
This study investigated the relationship between gender, school location and students mathematics achievements in secondary schools. Six secondary schools were selected, urban and rural areas with a total of 210 students, selected from all the sampled secondary schools. Mock Examination results in SS2 students were collected from the Benue State Examination Board (BSEB) and analyzed using Mean, Standard deviation and person's correlation coefficient. Two research questions and hypothesis were formulated and tested. The result revealed that gender, and school location has no significant relationship with students' recommendations were made as well as suggested for further study.
\end{abstract}




\section{Introduction}

\subsection{Background of the study}

Is male's superiority in mathematics genetically programmed efforts at addressing this question dominated the $20^{\text {th }}$ century and the increasing influence of feminist perspective has stimulated many large scale in the $21^{\text {st }}$ century. Obviously, males and females in view of their biological structures are naturally different. While are physically strong the females are weaker and this sometimes create poor patronage in physically demanding career by females (Awofala, 2007). Certainly many more males than females are in engineering, medicine or any science related careers which are physically demanding and use advanced mathematics beyond arithmetic (Fennema, 1979).

The topic of this study is premised on the current world trend and research emphasis on gender equity following the millennium declaration of September 2000 (United Nations 2000) and the agenda for the future developed at the 1997 UNESCO conference, (UNESCO 1997) Both organization sought the promotion gender equity, the empowerment of women and the elimination of gender inequality at all levels of education. Despite this bold attempts gender inequality in education generally and in mathematics education in particular has remained a global phenomenon (Awofola, 2007, Reid, 2003 and UNESCO 2003).

The educational standard in Nigeria has reached an optimal of diminishing return as the failure rate at each level increases with each passing day. This has given rise to so many research projects on students' achievements in mathematics.

The poor performance in external examinations especially in secondary schools certificate examination (GCE) by students has become a source of worry for stakeholders in the educational 
sector, especially in view of the nation's goal to be one of the world's top 20 economies by 2020 . Recent statistics released by the two examination bodies show that the standard of teaching and learning especially in mathematics have continued to wane at an alarming rate (Ugochi, 2009) of the 102 schools selected for evaluation using the quality assurance for basic and secondary education in Nigeria only six schools were rated good, 28 schools fair, 65 schools poor, while 3 schools were very poor.

Expectedly, the minister of Education Prof. Rugayyatu Ahmed Rufai expressed dismay over the poor performance and warned the teachers to brace up or face the wrath of government. According to her, there is a link between students' poor performance in school and the inefficiency of teachers and school managers.

Minister of the Federal Capital Territory (FCT) Sen. Bala Mohammed called for urgent need to pay attention to teachers training and development, teachers' development is the first step to take in our quest for rebuilding of our educational system.

School location is a variable in achievement that tends to also affects students in learning of mathematics. While rural students tend to manifest simpler social relationships due to greater inter-personal ties in rural settings (Bassey, Joshua and Asim, 2008) urban students show complex social relationships. Thus, one is led to wonder whether this affects the performance of secondary school students in Makurdi Local government area of Benue State. While it may be difficult for school to usually change its location, the location conceivably may have great consequences for how well students learnt at the school.

Previous researches have so much laid emphasis on teachers' competence, attitude and method of teaching as having effects on students' achievements in mathematics, but much attention has 
not been given to the fact that gender and school location could also stand a chance of having a relationship with students' achievement in mathematics. Therefore the researcher is interested in finding what relationship, gender and school location has on students' achievement in mathematics so as to have a holistic view of the possible factor responsible for the poor performance in secondary school mathematics. Seeing that mathematics as a subject is indispensable and remains the gateway to virtually all occupations.

\subsection{Statement of Problems}

Throughout the senior secondary school years, male superiority in mathematics is well pronounced (Blithe, Forbes, 1994) and more males than females are usually reported as doing better on problem solving tasks and applications. (Amstrong, 1981).

\subsection{Purpose of the Study}

Many investigations have been carried out by innumerable researchers (Maduabum and Odili, 2006), Nneji, (1999), Azuka, (2003), on the poor performance of children in secondary schools. However, the researcher found out that there's an existing a relationship between gender and school location with students achievements in mathematics but has not been adequately investigated. The purpose of this study therefore is to investigate to the extent to which the students' achievement in mathematics at the secondary school level could be as a result of the relationship between gender and school location. More specifically,

1. To determine the relationship of gender with students achievement in secondary school mathematics. 
2. To find out the relationship of school location with students achievement in secondary school mathematics.

\subsection{Research Questions}

Two research questions were formulated for this investigation to achieve the objective of the study. These are:

1. What relationship has gender with the achievement of students in mathematics?

2. What relationship has school location with the achievement of students in mathematics?

\subsection{Research Hypotheses}

The following hypotheses guided the study;

1. Gender has no significant relationship with students' achievement in secondary school mathematics.

2. School location has no significant relationship with students' achievement in secondary school mathematics.

\subsection{Significance of the Study}

The annual turnout of low achievement in mathematics in secondary schools is a matter of great concern (Okwagwajo, 1999). It is no doubt that mathematics is the subject on which science and technology is based. It is with the knowledge or background that this research works 
is designed to ascertain without doubt whether gender; and school location have relationships with students' achievement in mathematics.

This work will therefore be of great importance to educationists and policy makers in mathematics education. Since it is aimed towards improving the teaching and learning of mathematics in secondary schools, it will therefore enable policy makers adjust their policies to take care of gender and school location.

To the parents it is aimed at making them know some reasons why their children have been performing well in mathematics, with this knowledge, the parents will be able to assist the government and other educational institutions in finding solutions to the causes of the low achievement of their children in secondary school mathematics.

This research will also be of great significance to the teachers as it unveils the relationship between gender and school location with students achievement in mathematics. And hence motivate them to go to self-criticism in order to find out their inabilities and thus mark-out strategies to improve on their teaching.

Finally, the significance of this research to the government cannot be overemphasized. This will make the government to allocate more funds to schools giving preference to those in rural areas and also pay attention to strict and regular supervision in schools which will help in addressing the effects of these relationships on students' achievement in mathematics.

\subsection{Delimitations of the Study}


This research study covers only Makurdi local government area. The research is further limited to Mock results of SS2 students since Mock results are more readily available to the researcher.

\subsection{Definition Of Terms}

Relationship: Refers to the way in which gender, school location and students achievement in mathematics are connected.

Achievement: This is something that somebody has done successfully especially using his own efforts and skills.

Gender Difference: Refers to the difference in male and female students in mathematics achievement.

School Location: Refers to a geographical area in which a school is situated or found in rural or urban centers. 


\section{METHODOLOGY}

\subsection{Introduction}

Here the researcher defines the research design, population, area of study, sample instrument, method of data collection and method of data analysis.

\subsection{Research Design}

The researcher will adopt the ex-post facto design which is concerned mainly with finding and describing what is already in existence. The research is aimed at investigating, finding and describing the relationship between gender, school location and mathematics achievement in secondary schools.

\subsection{Area of Study}

The research will be carried out in Makurdi local government area of Benue State, Nigeria. Makurdi local government was created in 1970 and is in the northern part of Benue State. Guma bounds the local government in the south and Gwer-West bounds the local government on the west. It is also the headquarters of Benue State. It became the capital of Benue State in 1975 when the Benue-Plateau was split into two states namely, Benue and Plateau States.

Makurdi stands on both sides of River Benue thereby serving as a river port which separates the northern and southern parts of the town into two parts which are connected by two bridges.

Makurdi is also an important military base in the country with the presence of one of Nigeria's pit forces bases and Nigerian Army School of Military Engineering (NASME) 
and 72 airs borne battalion army in town. All of these military bases have secondary schools.

\subsection{Population of the Study}

The target population of this research is all SS2 mathematics students in the secondary schools in Makurdi local government. This was chosen because this research work is the relationship between genders, school location and students' achievement in mathematics. These secondary schools among those depicted as poor in mathematics.

\subsection{Sample and Sample Technique}

A simple random sampling procedure was used to select 210 students from six secondary schools located in both urban and rural areas. 105 male students were selected and 105 females students for the study. Thirty-five (35) students were chosen from each school. These schools include:

\begin{tabular}{|l|l|l|}
\hline S/N & School & No. of sampled students \\
\hline 1 & Apostolic Secondary School Adeke & 35 \\
\hline 2 & Government College Yagba & 35 \\
\hline 3 & Triumph Secondary School & 35 \\
\hline 4 & Ecwa Secondary School & 35 \\
\hline 5 & Tilley Gyado Secondary School & 35 \\
\hline 6 & Good news Secondary School & 35 \\
\hline
\end{tabular}




\subsection{Instrument of the Study}

The researcher will make use of Mock Examinations of SS2 students because they are more readily accessible by him.

\subsection{Validation of Instrument}

The instrument for data collection will first be validated by experts in mathematics education. Necessary corrections will be made in terms of inadequacy of items and content coverage in respect to research objectives and research questions. A reliability coefficient of at least 0.75 should be recorded, showing the instrument is reliable.

\subsection{Method of Data Collection}

The method used for data collection will be by personal contact. The researcher will go to Benue State Examination Board (BSEB) to collect the data. The researcher will collect Mock Examinations of SS2 students for 2012 and 2013.

\subsection{Method of Data Analysis}

The data for the study will be obtained from the Benue State Examination Board by the researcher. The mean and standard deviation will be used to answer the research questions. Pearson Product Moment Correlation Coefficient will be used to test the null hypothesis at 0.05 level of significance. 


\section{DATA PRESENTATION, ANALYSIS, INTERPRETATION AND DISCUSSION OF FINDINGS}

\subsection{Data Representation, Interpretation and Analysis}

The researcher took the analysis of the scores of students' Mock Examinations for 2012 and 2013. The results are stated below.

Research question 1: What relationship has gender with the achievement of students in Mathematics?

Table 1: Correlation, Mean and Standard deviation analysis of gender achievement in mathematics;

\begin{tabular}{|l|l|l|l|l|l|l|}
\hline Year & Variable & $\mathbf{N}$ & Mean & Student & Pearson correlation & Sig \\
\hline 2012 & Male & 100 & 58.05 & 11.501 & & 0.170 \\
& Female & 100 & 60.10 & 9.974 & & \\
\hline 2013 & Male & 105 & 48.15 & 9.047 & & 0.895 \\
& Female & 105 & 47.24 & 9.224 & & \\
\hline
\end{tabular}


Table 1 shows that the female students obtained a higher mean performance score in mathematics $(\mathrm{x}=60.10, \mathrm{SD}=9.974)$ than their male counterparts $(\mathrm{x}=58.05, \mathrm{SD}=11.501$ in 2012 and the male students obtained a higher mean performance score in mathematics $(x=48.15, S D$ $=9.047)$

Research question 2: What relationship has school location with students' achievement in mathematics?

Table 2: Correlation, Mean and Standard deviation analysis of school location achievement in mathematics;

\begin{tabular}{|l|l|l|l|l|l|l|}
\hline Year & Variable & N & Mean & Student & Pearson correlation & Sig \\
\hline 2012 & Urban & 107 & 60.32 & 6.361 & & \\
& Rural & 107 & 54.20 & 7.905 & 0.101 & \\
& Urban & 105 & 64.57 & 7.472 & & 0.669 \\
& Rural & 105 & 56.29 & 8.907 & -0.042 & \\
\hline
\end{tabular}

Table 2 shows that the urban students obtained higher mean performance score in mathematics $(\mathrm{x}=60.32, \mathrm{SD}=6.361)$ than their rural counterparts $(\mathrm{x}=54.20, \mathrm{SD}=7.905)$.

\subsubsection{Hypothesis testing}


Research Hypothesis 1: Gender has no significant relationship with students' achievement in secondary school mathematics.

Table 1 shows that there is no significant difference $(r=-0138 ; p=0.170 ; p>0.05)$ in 2012 and $(r$ $=0.013 ; p=0.895 ; p>0.05)$ in 2013. Hence it is concluded that there is no significant difference between gender and students' achievement in mathematics.

Research Hypothesis 2: School location has no significant difference $(r=0.101 ; p=0.301$; $\mathrm{p}>0.05)$ in 2012 and $(r=-0.042 ; p=0.669 ; p>0.05)$ in 2013. Hence it is concluded that there was no significant difference in the relationship between school location and students' achievement in secondary school mathematics.

\subsection{Discussion Findings}

\section{Hypothesis 1:}

The yearly performance of students in Mock Examinations as can be seen from table 1 and table 3 indicates that there is no significant difference in the relationship between gender and students' achievement in secondary schools mathematics.

These findings are consistent with popular results obtained in gender literature i.e the results are in agreement with Jerry and Kurumeh (2013), Okwu and Aligba (2004) who all reported that there is no relationship between gender and students achievement in secondary school mathematics.

These findings also supports Leahey and Guo (2001), Ericikan, Mclereikth and Lapointe (2005) and (Abe, 2004, Lynn and Jaan, 2008) who reported that there were no significant difference when considering gender as relating to gender sex difference in mathematics. 


\section{Hypothesis 2:}

From $t$ able 2 the study obviously showed no significant difference in the relationship between school location and students achievement in mathematics. The result findings support Kissau(2006) who reported that students in urban and rural locations performed in a similar manner.

Also, Lee and Mchtire (2000) reported that rural school's achievement varies across states and so no definite study can apply to all rural areas, so other researchers find no difference in the achievement of rural and non-rural students as stated by Hopkins (2004) 


\section{SUMMARY, CONCLUSION, RECOMMENDATIONS AND SUGGESTIONS}

\subsection{Introduction}

This chapter is concerned with the summary, recommendation, conclusion and suggestions for further study. The summary streamlines the important findings in research while conclusion gives and overview of the findings, observation and comments. Lastly, recommendation on the problems associated with achievement of students in secondary school mathematics

\subsection{Summary}

The research work was to find out whether there is a relationship between genders, school location and students' achievement in secondary school mathematics in Makurdi local government area of Benue State, as a result of poor performance of students in mathematics. Also the research was to find out if there was a difference in the relationship between gender and students' achievement in secondary school mathematics, school location and students' achievement in mathematics.

For this purpose research questions were formulated to guide the researcher. The hypotheses were tested using Pearson correlation coefficient, data was collected by the researcher from the Benue State Examination Board (BSEB), from past records of Mock examinations. The samples for the study included secondary schools in Makurdi located in both urban and rural areas.

From the analysis of data collected, it was observed that there is no significant difference in the relationship of both gender and school location with students' achievement in mathematics. 
This implied that gender and school location has nothing to do with students' performance in secondary school mathematics.

Based on the findings some recommendations and suggestions for further study were made.

\subsection{Conclusion}

It can be concluded based on the findings of the study that there is no significant difference in the relationship between gender and school location with students' mathematics achievement in secondary schools in Makurdi.

From the analysis of the study it can be deduced that there is disparity in the academic achievement of male students to female students and urban to rural when comparing means. However, it can be observed that lack of basic facilities like classrooms, mathematics textbooks, libraries, laboratories etc, can affect the achievement of students as well as unqualified teachers.

It is clear from the analysis that there is no significant relationship as to the relationship between gender and school location with students achievement in mathematics. But, when students are exposed to social ills like illicit sex which may result to unwanted pregnancies, the male students indulge themselves in alcohol drinking, stealing and engage in cult activities also. Activities like this cannot enhance good performance of students in the subject, and as such, the students end up achieving less in mathematics.

\subsection{Recommendations}

On the basis of research findings, the following recommendations are made:

1. There is need to improve on the resources (human and material) available in both rural and urban located schools. 
2. Government should ensure that there is even distribution of teachers in schools.

3. Education administrators should improve on their inspection exercise.

4. Refreshers courses and workshops as well as seminars should be organized to re-orient teachers, students and parents that when considering gender and school location there is no significant difference in the relationship with students' achievement in mathematics.

5. Government of Benue State as well as philanthropic organizations should strongly encourage the study of mathematics by creating incentives to motivate prospective mathematicians.

\subsection{Suggestions for Further Study}

The school system is undoubtedly plagued with many problems, as such; this cannot claim to have adequately addressed itself to all its areas that need attention. More so, when the study is restricted to a small area, even the findings as revealed by the study of the area covered cannot in any way be claimed to be exhaustive.

However, another investigation covering a wider range involving more schools and local governments in Benue State should be carried out on the findings as revealed that the area of study covered cannot be exhaustive.

Finally, since the researcher's sample is not large enough, the researcher advocates for more detailed work involving more schools, local governments, states and indeed the whole country in order to have a better view of each system of education. 


\section{References}

Abe, T.O (2004). Comparative study of family type, sex and difference in academic achievement of students in Mathematics. Journal of Curriculum studies Department, 3, 33-44

Armstrong J.M. (1981). Achievement and Participation of women in mathematics Education, vol. 12. 356-372.

Awofala A.O.A (2007). Women and learning of mathematics. Africa Journal of Historical sciences vol3, 195-213

Barker,B. (1997). Girls' World or anxious times: What's really happening at school in the gender war? Education Review 49, 221-227

Bassey, S.W, Joshua, M.T and Asim, A.E (2008) Gender differences and mathematics achievement of rural senior secondary students in Cross River State, Nigeria, Proceedings of international conference to Review Research in science, technology and mathematics Education (epusteme-2) Mumbai India.

Battistich, .V. Solomon, D, Kim, D. Watson, M. and Schaps, E (1995). School as communities, Poverty levels of students' populations and students motives, and performance: a multilevel analysis. American Education Research Journal, 32, 627-658.

Beller, .M. and Gafni, N (1996). The 1991 international assessment of educational progress I mathematics and sciences: the gender difference perspective. Journal of Educational psychology, $88,3,365-377$.

Blithe T. Forbes. S, Clark M and Robinson. E (1994). Gender difference in New Zealand Mathematics performance at the secondary-tertiary interface. International journal of Educational psychology Research vol. 21, 427- 428

Bush W.S (2005) Improving Research on Mathematics Learning and Teaching in Rural contact. Journal of Research in Rural Education.

Ericikan, K. McCreith, T. Lapointe, V. (2005) Factors associated with mathematics achievement and participation in advanced mathematics courses: An examination of gender difference form an international perspective school and mathematics, 105,5.

Fennema .E. (1979) Women and Girls in Mathematics-equity in Mathematics, vol.10. 389-401

Finn, J.D, Dwberg, L and Reis, .J. (1997) Sex differences in educational attainment: acrossnation Perspective. Harvard Educational Review, 49, 477-503

Hedges, L.V, and Nowell, A. (1995) Sex difference in mental test scores, variability, and numbers of high scoring individuals. Science, 269, 41-45 
Igboegwu E.N, and Okwonkwo, G.A (2009). Influence of gender and location of school on students achievement in chemistry. Journal of Research in education vol. 1, 1-9

Jegede, O.J. and Inyang, N (1990) Gender differences and achievement intergrated science among junior secondary school students. A Nigerian study. International Review of Education,363-368

Jerry E.O and Kurumeh M.S (2013) Gender and location as correlates of Achievement in Number and Numeration using Ethno Mathematics Approach in the Junior secondary schools in Benue State. Greener journal of Educational Research vol 3(4), 184-190

Kagan .J. (1971) change and continuity in infancy, New York. John Wiley and sons.

Kissau, S. (2006) Gender difference in motivation to learn French, Canadian Modern Language Review, 63(3), 65-96

Knodel, J. (1997). The closing of the gender gap in schooling. The case of Thailand comparative Education, 33, 61-86

Kolnwole, E.B (2002) Sex differences in academic achievement in science subjects in Nigeria tertiary institution. Research in curriculum studies, 2, 168-173.

Lee, J and Militre, W.G. (2000) interstate variation in mathematics achievement of rural and Non-rural students. Journal of research in rural education 16(3) 168-181

Leahey, E and GUO, G. (2001) Differences in mathematical trajectories, social forces, 80, 713732

Lynn; R and Jaan .M. (2008), science. Sex differences in attainment. The journal of social, political and economic studies 33(1), 101-124

Nneji, BC (1999), factors encouraging poor performance of students in secondary schools. Journal of environmental factors of failure. 2(1) 19-27

Odo, T.O (1999). Gender school location as factors of students' difficulty in secondary schools mathematics; improving students' interest in mathematics through concept mapping technique: focus on gender, journal of research in curriculum and teaching. 1(1). 30-38

Okwagwajo, S.B (1999). Education and technological development. London; Evans brothers limited.

Okwu E.I and Aligba S.O (2004). The effect of gender and location and mathematics achievement of secondary school students.Benue State University; Journal of education. Vol. 5, 123-126 
Owoeye, J.S. (2002) the effect of integration of location, facilities and class size on academic achievement of secondary school students in Ekiti state university, unpublished PhD dissertation, university Ibadan.

Pervin, L.A (1978) current controversies: issues in personalities: New York: rjohn wiley and sons.

Peterson, P and Fennema, e (1985). Effective teaching, students' engagement in classroom activities, and sex related differences in learning mathematics. American educational research journal, 22, 309-335

Ranhawa, B.S. (1994). Self-efficacy in mathematics, attitudes and achievement of boys and girls from restricted samples in two countries; Perceptual and motor skills, 79, 1011-1018.

Reid, N. (2003) gender and physics international journal of science education, vol. 25, 509-536

UNESCO (2003), gender and education for equality global

Monitoring report 2003/2004 (online), available at http://www.unesco/oc.unesco.org/education/eta-report/2003pdf/chapter 3

United Nations (2000). U.N millennium declaration 55/2 resolution adapted by the general assembly, (online) Available at http://www.un.org/milleniumgoals.

Yusuf, M.A and Adigun, J.T (2010) the influence of school sex, location and type on students' academic performance international journal of education science 2(2). 81-85 